\title{
LEARNING TO \\ READ TALMUD \\ What It Looks Like and How It Happens
}


The research for this book and its publication were made possible by the generous support of the Jack, Joseph and Morton Mandel Center for Studies in Jewish Education, a partnership between Brandeis University and the Jack, Joseph, and Morton Mandel Foundation of Cleveland, Ohio.

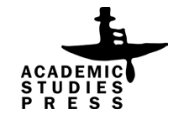




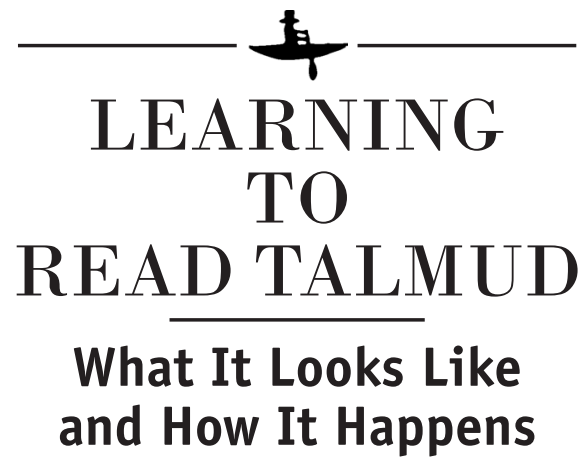

Edited By JANE L. KANAREK and

MARJORIE LEHMAN 


\section{Library of Congress Cataloging-in-Publication Data:}

The bibliographic record for this title is available from the Library of Congress.

ISBN 978-1-61811-513-3 (hardback)

ISBN 978-1-61811-577-5 (paperback)

ISBN 978-1-61811-514-0 (electronic)

ISBN 978-1-64469-243-1 (open access)

(C) Academic Studies Press, 2016

(c) Jane L. Kanarek \& Marjorie Lehman, 2019

Book design by Kryon Publishing, www.kryonpublishing.com Cover design by Ivan Grave.

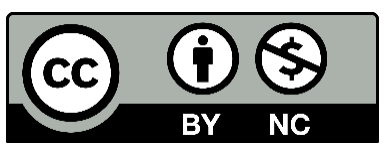

Effective July 24th, 2019, this book will be subject to a CC-BY-NC license. To view a copy of this license, visit https://creativecommons.org/licenses/by-nc/4.0/. Other than as provided by these licenses, no part of this book may be reproduced, transmitted, or displayed by any electronic or mechanical means without permission from the publisher or as permitted by law.

The open access publication of this volume is made possible by the generous support of the Jack, Joseph and Morton Mandel Center for Studies in Jewish Education, a partnership between Brandeis University and the Jack, Joseph and Morton Mandel Foundation of Cleveland, Ohio.

Published by Academic Studies Press 28 Montfern Avenue

Brighton, MA 02135, USA

press@academicstudiespress.com

www.academicstudiespress.com

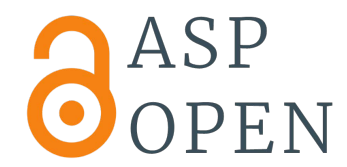

Increasing discoverability. Democratizing research. www.academicstudiespress.com/aspopen 
For our parents, who first taught us how to read Anna C.V. and David J. Kanarek Sheila K. and Wallace B. Lehman 